\title{
David Fraser Fraser-Harris, D.Sc., M.D.
}

DAVID Fraser Fraser-Harris was born in Edinburgh in 1857 , the son of David Harris, F.R.S.E., and Elizabeth Fraser, daughter of Sheriff Fraser, of Kamsky. From Dr Bryce's Collegiate School he went to Edinburgh and Glasgow Universities, and did post-graduate work in Berne, Jena and Zurich. In Glasgow he was President of the S.R.C., and he returned to that University in 1893 as senior assistant to Professor J. G. McKendrick, and Muirhead Demonstrator in Physiology.

In 1898 Fraser-Harris came to St Andrews University, then in a difficult period of transition, and helped for ten years to establish for the first time a teaching department of Physiology. While there he married Eleanor, youngest daughter of Lieut.-Col. F. M. Hunter, C.B., C.S.I., by whom he had one son, now a Sub-lieutenant in the Royal Navy. After working for a time under Professor Carlier in Birmingham, Fraser-Harris became, in I9II, Professor of Physiology in Dalhousie University, Halifax, Nova Scotia; and here he had once again the difficult task of creating a new physiological school and laboratory. Here, among many other publications, he wrote the official account, on the medical side, of the great disaster caused by the explosion of an ammunition ship, which destroyed half the town with appalling loss of life, in 1917.

In 1924 Fraser-Harris suffered a breakdown in health, which, though he afterwards made a good recovery, seemed at the time so serious that he retired on a "disability pension" from his Chair. His resignation was regretted by all his colleagues; he was an extremely competent teacher, he was known as a lecturer all over Canada, and simplicity, unselfishness and a turn of kindly humour endeared him to his friends.

Returning to London with his health more or less restored, FraserHarris took up literary work with much courage and assiduity in scientific and medical journalism and especially in connection with the history of medicine, a subject to which he had given years of study. He wrote among other things a History of Welsh Medicine, and in 1933 he won a prize from Glasgow University for an Essay on "Antiseptics before Lister." He was a well-known member of the Athenæum in his latter years.

Lack of robust health, the drudgery of teaching, and constant lack of such resources as a modern laboratory affords and modern investiga- 
tions require, are sufficient reasons for a somewhat scanty output of research. But his friends know that his mind was ever active, his scientific curiosity never abated, and many troubles never embittered his cheerful disposition.

He was elected a Fellow of this Society in I 896 , and died on January 3, 1937.

The following are a few of his various publications:-

"On the Stereophotochromoscope, a new optical instrument," Proc. Phil. Soc. Glasgow, I895; Journ. Anat. Physiol., 1896.

"On the chemistry and coagulation of Milk," Journ. Anat. Physiol., I 895; Proc. Roy. Soc. Edin., I 897.

"On Hæmatoporphyrinuria," Journ. Anat. Physiol., I897; Brit. Med. Journ., I 898 .

“On Maté, or Paraguay Tea" (with J. G. McKendrick), Pharmaceut. Journ., 1898 .

"On post-tetanic tremor," Journ. Physiol., I903; ibid. (with J. Moodie), I 906.

"On the use of soluble prussian blue for investigating the reducing power of animal bioplasm" (with J. C. Irvine), Biochem. Journ., I906; and (with W. Moodie) Journ. Physiol., 1906.

"On the tremors of striated muscle," various papers in Journ. Physiol., I $906-$ I 909 .

"Observations on Frogs at temperatures below zero," Journ. Physiol., I9IO.

“Harvey v. Caesalpinus," I 7th Int. Congress Med. London, I9I3.

"Spectroscopic investigation of the reduction of hæmoglobin by reductase" (with H. J. M. Creighton), Journ. Biol. Chem., I9I 5.

"The reality of nerve-energy," Brit. Journ. Med. Psychol., I927.

D. W. T. 